\title{
THE IMPACT OF SEWAGE TREATMENT PLANT ON THE AMOUNT OF HEAVY METALS IN WATER OF THE SUPRAŚL RIVER CATCHMENT AREA
}

\author{
Mirosław Skorbiłowicz' ${ }^{1}$ Elżbieta Skorbiłowicz'1, Paulina Wójtowicz'1, \\ Piotr Ofman ${ }^{1}$, Emilia Zamojska' \\ 1 Department of Technology in Engineering and Environmental Protection, Bialystok University of Technology, \\ Wiejska Str. 45A, 15-351 Białystok, Poland, e-mail: m.skorbilowicz@pb.edu.pl
}

Received: 2015.11.12

Accepted: 2015.12.09

Published: 2016.01.06

\begin{abstract}
The main purpose of this study was to evaluate the effect of treated sewage flowing from sewage treatment plants located in the basin of the Supraśl river on the concentration and load of metals in river waters and its main tributaries. Three measuring-control points were chosen, on the river and its tributaries, located near Gródek, Sokółka and Dobrzyniewo. Selected points were located behind the discharge of treated wastewater from sewage treatment plants respectively - Gródek, Sokółka and Bialystok. The samples of treated sewage and water were collected in a period from May to November, once a month in 2014. Each individual sample was examined for the content of dissolved form of the following metals: $\mathrm{Pb}^{2+}, \mathrm{Cu}^{2+}, \mathrm{Cd}^{2+}, \mathrm{Ni}^{2+}, \mathrm{Zn}^{2+}, \mathrm{Fe}^{2+/ 3+}$. After taking into account water flow of the Biała, Sokołda and Supraśl in every month, metals loads expressed in $\mathrm{mg} \cdot \mathrm{h}^{-1}$, transported by the Supraśl and its tributaries waters were calculated. In the study monthly metals loads discharged into the Biała, Sokołda and Supraśl by sewage treatment plants in Białystok, Sokółka and Gródek were also calculated. The studies have shown the impact of metals load in treated wastewater on metals loads in waters of studied rivers based on the obtained correlation. Most of the searched relations between loafs of $\mathrm{Pb}^{2+}-\mathrm{r}=0,88 ; \mathrm{Cd}^{2+}-\mathrm{r}=0,98 ; \mathrm{Fe}^{2+/ 3+}-\mathrm{r}=0,45 ; \mathrm{Ni}^{2+}-\mathrm{r}=0,55 ; \mathrm{Zn}^{2+}$ $-\mathrm{r}=0,86$ were obtained in case of wastewater treatment plant in Gródek and Supraśl waters. In the study period we observed a diversity in concentration of $\mathrm{Cd}^{2+}, \mathrm{Fe}^{2+/ 3+}, \mathrm{Ni}^{2+}$ and $\mathrm{Zn}^{2+}$ in treated sewage and in river waters, which affected loads of this metals.
\end{abstract}

Keywords: sewage treatment plant, heavy metals, water.

\section{INTRODUCTION}

The inorganic contaminants include metals in the environment. As heavy metals are defined as those whose specific weight exceeds $5 \mathrm{~g} \cdot \mathrm{cm}^{-3}$. This group includes, among others, chromium $(\mathrm{Cr})$, cadmium $\left(\mathrm{Cd}^{2+}\right)$, nickel $\left(\mathrm{Ni}^{2+}\right)$ and lead $\left(\mathrm{Pb}^{2+}\right)$ and microelements - zinc $\left(\mathrm{Zn}^{2+}\right)$ and copper $\left(\mathrm{Cu}^{2+}\right)$. Most of them are highly toxic and dangerous they accumulate in the environment and causes downturn, mainly in biochemical processes of organic matter decomposition, including a reduction in the efficiency of biological sewage treatment plants and water purifying process [Florczyk and Gołowin 1980, Hermanowicz et al. 1999, Brzóska et al. 2007].
The content of metals in natural waters is low. The most important source is land leaching, containing metals in its composition [Duffy and vanLoon 2008]. They can penetrate waters with their runoffs. An important anthropogenic source are industrial waste water mainly from the chemical, metallurgical and galvanic facilities [Kociołek-Balawejder and Stanisławska 2012]. The source of increased metal content can also be corroded pipelines and tanks, made of raw materials, which was composed from these elements [Hermanowicz et al. 1999]. Increased metals amounts in environment contributes to the intensification of agriculture and transport development [Duffy and van Loon 2008, Piekutin 2008]. Metals occurrence in surface waters 
are mostly affected by the type and degree of catchment urbanization.

The aim of this study was to evaluate the effect of the treated sewage flowing from sewage treatment plants located in the Supraśl basin on the concentration and metals loads in river water and its main tributaries.

\section{METHODS}

The Supraśl length is 93.8 kilometers, making it the second largest river in Podlaskie [Skorbiłowicz 2010]. It is a tortuous and meandering lowland river, which is characterized by a small decline $(0.76 \%$ ) with an average flow of $4.18 \mathrm{~m}^{3} \cdot \mathrm{s}^{-1}$. It flows in a well-shaped, broad valley. It begins its run near the village of Topolany and heads eastwards. By Michałowo it turns north and runs through Gródek, followed by a large part of Knyszyńska Forest. Then, it passes Supraśl and Wasilków and in the village of Złotoria it falls into the Narew on 299.8 kilometers of its course.

Its two main tributaries are the Słoja and Sokołda. Płoska and Biała also falls to the Supraśl river, which is main receiver of the treated sewage from plant in Białystok. In Wasilkow the Supraśl waters are used as drinking water for Białystok, which contributed to protection zone embrace. Forests cover $30 \%$ of the catchment area. A large share of which are also wetlands and peat bogs. On the Supraśl river and its tributaries, 3 measuring - control points were chosen, located near Gródek, Sokółka and Dobrzyniewo. Selected points were located behind the discharge of treated wastewater from sewage treatment plants Gródek, Sokółka and Białystok (Figure 1).

The sewage treatment process in Bialystok is based on activated sludge method. In the technological wastewater treatment stands out mechani- cal and biological node. Wastewater treatment plant in Bialystok is one of the largest facilities in Poland. The throughput is about $100,000 \mathrm{~m}^{3} \cdot \mathrm{d}^{-1}$. The operation principle of sewage treatment plants in Sokółka is based on activated sludge method, which is implemented in sequential biological reactors. The reactor operating cycle is about 8 hours. The capacity of sewage treatment plant in Sokółka is up to $6000 \mathrm{~m}^{3} \cdot \mathrm{d}^{-1}$. In that facility domestic wastewater with small amount of industrial wastewater is treated. Similarly to the Sokółka, wastewater treatment plant in Gródek is based on activated sludge method which is implemented in sequential biological reactors. Reactor cycle is about 1.5-2 hours. The capacity of sewage treatment plants in Gródek is about $80 \mathrm{~m}^{3} \cdot \mathrm{d}^{-1}$.

The samples of treated sewage and water were collected in period from May to November, once a month in 2014.

Each individual sample was tested for concentration of dissolved form of the following metals: $\mathrm{Pb}^{2+}, \mathrm{Cu}^{2+}, \mathrm{Cd}^{2+}, \mathrm{Ni}^{2+}, \mathrm{Zn}^{2+}, \mathrm{Fe}^{2+/ 3+}$. After taking into account water flow of the Biała, Sokołda and Supraśl in every research month metal loads expressed in $\mathrm{mg} \cdot \mathrm{h}^{-1}$, transported by the Sypraśl waters and its tributaries were calculated. In the study monthly metals loads discharged into the Biała, Sokołda and Supraśl by sewage treatment plants in Białystok, Sokółka and Gródek were also calculated.

The contents of the analyzed elements was determined by atomic absorption spectrometry (AAS) using a Varian SpectrAA type - 100. The source of the oxidizing flame was air-acetylene. Each sample before the assay was acidified to $\mathrm{pH} \approx 2$.

Statistical analysis was performed with Statistica software licensed version 10.0. The scope of the analysis included descriptive basic measures, the arithmetic mean, median, minimum, maximum and standard deviation. Pearson cor-

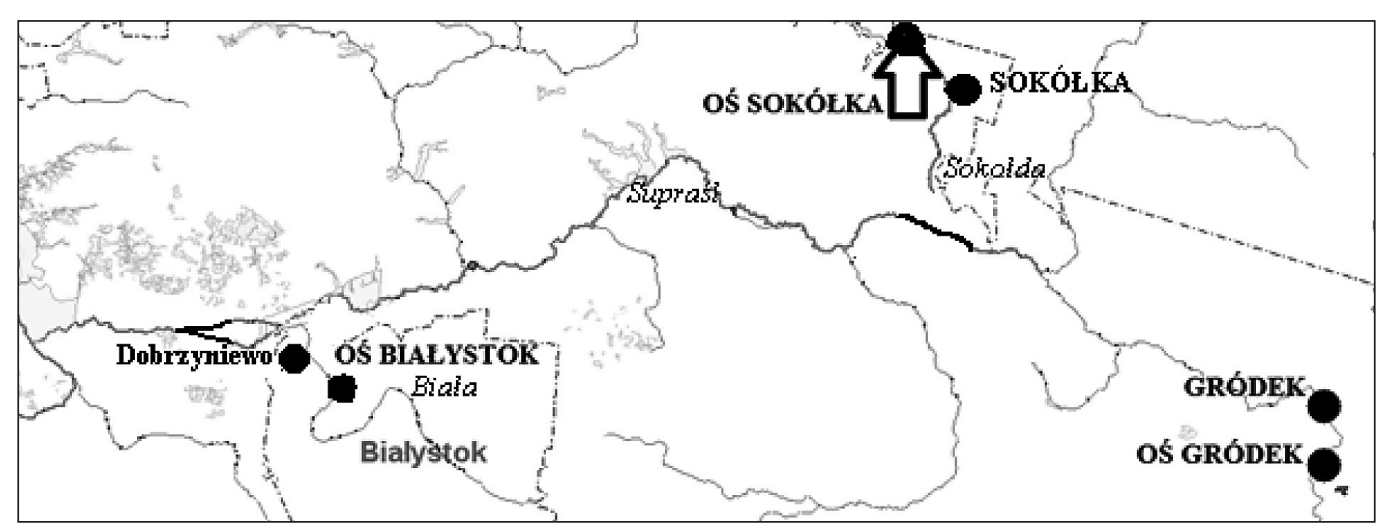

Figure 1. Measurement points in Supraśl basin [geomelio.pl] 
relation coefficients were determined between the metal loads in the Biała, Sokołda and Suprasl and purified wastewater from individual waste water treatment plant. The flow of river waters at some points was defined complementary based on a mathematical method proposed by Brykała [2009].

\section{RESULTS AND DISCUSSION}

The studies have shown the highest concentration of $\mathrm{Pb}^{2+}$ in Sokołda waters at the point of Sokółka, which amounted to $0.015 \mathrm{mg} \cdot \mathrm{dm}^{-3}$. In contrast, concentrations observed in Gródek and Dobrzyniewo were similar and were respectively equal to 0.010 and $0.011 \mathrm{mg} \cdot \mathrm{dm}^{-3}$ (Tab. 1). Slightly higher range of this element concentrations was observed by Trawczyńską et al. [2009] in the waters of Bzura rivers. Depending on the measurement point authors report $\mathrm{Pb}^{2+}$ concentration from 0.001 to $0.033 \mathrm{mg} \cdot \mathrm{dm}^{-3}$ and point out the pollution of Poland rivers with lead. Therefore, it is difficult to determine the natural amount of the element present in the surface waters.

The concentration of $\mathrm{Cd}^{2+}$ in each point was relatively uniform. The smallest concentration of this element was observed at the point of Sokółka and the highest in Dobrzyniewo (Table. 1). The observed values were equal to 0.004 and 0.007 $\mathrm{mg} \cdot \mathrm{dm}^{-3}$ respectively. Slightly higher concentration compared to that observed in Sokółka was achieved in Gródek $\left(0.005 \mathrm{mg} \cdot \mathrm{dm}^{-3}\right)$. Much lower concentration of $\mathrm{Cd}^{2+}$ was observed by Palapa and Maramis [2015] in studies on the quality of water in a small stream flowing through Talawaan, which is located in the vicinity of a gold mine in Indonesia. Researchers obtained the con- centration of $\mathrm{Cd}^{2+}$ ranging from 0.0001 to 0.0004 $\mathrm{mg} \cdot \mathrm{dm}^{-3}$. As highlighted the values obtained by them are typical for the average concentration of this element in waters of other rivers in the region.

The concentrations of $\mathrm{Cu}^{2+}$ were very similar in each measuring point and amounted to 0.040, 0.050 and $0.060 \mathrm{mg} \cdot \mathrm{dm}^{-3}$ in Sokółka, Gródek and Dobrzyniewo (Table 1).

The concentration of $\mathrm{Fe}^{2+/ 3+}$ in Supraśl water observed in Gródek was equal to $0.86 \mathrm{mg} \cdot \mathrm{dm}^{-3}$. Slightly less iron was in the waters around Sokółka $\left(0.77 \mathrm{mg} \cdot \mathrm{dm}^{-3}\right)$, and the least in Dobrzyniewo $\left(0.51 \mathrm{mg} \cdot \mathrm{dm}^{-3}\right)$ (Table 1$)$. A greater range of concentrations of this element was obtained by Kaniuczak and Augustyn [2011] in the studies conducted in the river Wisłok. The observed amounts of $\mathrm{Fe}^{2+/ 3+}$ ranged between 0.080 and $2.870 \mathrm{mg} \cdot \mathrm{dm}^{-3}$.

The concentration of $\mathrm{Ni}^{2+}$ and $\mathrm{Zn}^{2+}$ were the least diverse from all the analyzed elements. In the case of nickel, the same concentration in water was reported in Gródek and Dobrzyniewo (0.040 $\left.\mathrm{mg} \cdot \mathrm{dm}^{-3}\right)$, while in Sokolka $\mathrm{Ni}^{2+}$ concentration reached almost twice as much $\left(0.070 \mathrm{mg} \mathrm{dm}^{-3}\right)$. In the waters of Gródek and Sokółka the same concentration of $\mathrm{Zn}^{2+}$ were observed amounting to $0,030 \mathrm{mg} \cdot \mathrm{dm}^{-3}$ in water of Dobrzyniewo $\mathrm{Zn}^{2+}$ concentraion was two times higher reaching a value of $0.060 \mathrm{mg} \cdot \mathrm{dm}^{-3}$.

Lead concentrations in treated wastewater from all the objects was similar (Table 2). The least of this element occurred in wastewater from treatment plant in Białystok and Gródek $\left(0.010 \mathrm{mg} \cdot \mathrm{dm}^{-3}\right)$. Slightly more lead was recorded in treated wastewater from the Sokółka $\left(0.011 \mathrm{mg} \cdot \mathrm{dm}^{-3}\right) . \mathrm{Cd}^{2+}$ concentration in treated wastewater from individual facilities was varied. Least $\mathrm{Cd}^{2+}$ was in treated wastewater from

Table 1. Average concentrations of metals in water behind the discharge of treated sewage

\begin{tabular}{|c|c|c|c|c|c|c|c|}
\hline \multirow{2}{*}{ Point } & $\mathrm{Pb}^{2+}$ & $\mathrm{Cd}^{2+}$ & $\mathrm{Cu}^{2+}$ & $\mathrm{Fe}^{2+/ 3+}$ & $\mathrm{Ni}^{2+}$ & $\mathrm{Zn}^{2+}$ \\
\cline { 2 - 8 } & \multicolumn{7}{|c|}{$\left[\mathrm{mg} \cdot \mathrm{dm}^{-3}\right]$} \\
\hline Gródek & 0.010 & 0.005 & 0.050 & 0.860 & 0.040 & 0.030 \\
\hline Sokółka & 0.015 & 0.004 & 0.040 & 0.770 & 0.070 & 0.030 \\
\hline Dobrzyniewo & 0.011 & 0.007 & 0.060 & 0.510 & 0.040 & 0.060 \\
\hline
\end{tabular}

Table 2. The average concentration of metals in treated wastewater

\begin{tabular}{|c|c|c|c|c|c|c|}
\hline \multirow{2}{*}{ Point } & $\mathrm{Pb}^{2+}$ & $\mathrm{Cd}^{2+}$ & $\mathrm{Cu}^{2+}$ & $\mathrm{Fe}^{2+/ 3+}$ & $\mathrm{Ni}^{2+}$ & $\mathrm{Zn}^{2+}$ \\
\hline & \multicolumn{6}{|c|}{$\left[\mathrm{mg} \cdot \mathrm{dm}^{-3}\right]$} \\
\hline OŚ Gródek & 0.010 & 0.009 & 0.060 & 0.700 & 0.020 & 0.120 \\
\hline OŚ Sokółka & 0.011 & 0.014 & 0.060 & 1.070 & 0.040 & 0.190 \\
\hline OŚ Białystok & 0.010 & 0.011 & 0.050 & 0.330 & 0.010 & 0.050 \\
\hline
\end{tabular}


Gródek $\left(0.009 \mathrm{mg} \cdot \mathrm{dm}^{-3}\right)$, while the highest in wastewater from sewage treatment plant in the Sokółka $\left(0.014 \mathrm{mg} \cdot \mathrm{dm}^{-3}\right)$. In turn, the concentration in treated wastewater from Bialystok was equal to $0.011 \mathrm{mg} \cdot \mathrm{dm}^{-3}$. Concentrations of $\mathrm{Cu}^{2+}$ in particular objects were very similar and ranged from 0.050 to $0.060 \mathrm{mg} \cdot \mathrm{dm}^{-3}$. The concentration of $\mathrm{Fe}^{2+/ 3+}$ varied. The least $\mathrm{Fe}^{2+/ 3+}$ was recorded in treated wastewater discharged from treatment plant in Białystok $\left(0.330 \mathrm{mg} \cdot \mathrm{dm}^{-3}\right)$. In wastewater discharged from Gródek, $\mathrm{Fe}^{2+/ 3+}$ level was more than twice as high as in treated wastewater from Bialystok $\left(0.700 \mathrm{mg} \cdot \mathrm{dm}^{-3}\right)$, but most of this element was in the wastewater from the Sokółka $\left(1,070 \mathrm{mg} \cdot \mathrm{dm}^{-3}\right)$. The concentrations of $\mathrm{Ni}^{2+}$ and $\mathrm{Zn}^{2+}$ were characterized by a similar distribution in treated wastewater in each facility. The maximum concentration of both elements were observed in wastewater from the Sokółka $(0.040$ $\mathrm{mg} \cdot \mathrm{dm}^{-3}$ for $\mathrm{Ni}^{2+}$ and $0.190 \mathrm{mg} \cdot \mathrm{dm}^{-3}$ for $\mathrm{Zn}^{2+}$ ). In turn, the minimum concentration of both elements occurred in sewage from Białystok equal respectively to $\mathrm{Ni}^{2+}$ and $\mathrm{Zn}^{2+} 0.010$ and $0.050 \mathrm{mg} \cdot \mathrm{dm}^{-3}$. However, in treated wastewater from Gródek the concentration of these elements for $\mathrm{Ni}^{2+}$ was $0,040 \mathrm{mg} \cdot \mathrm{dm}^{-3}$, while $0,120 \mathrm{mg} \mathrm{Zn}^{2+} \cdot \mathrm{dm}^{-3}$.

For all the studied elements, none of the studied facilities exceeded the limits set by the Regulation of the Minister of Environment of 18 November 2014 on the conditions to be met when introducing sewage into water or soil and on substances particularly harmful to the aquatic environment.
Loads of individual elements within the study period were relatively balanced, as evidenced by similar values of arithmetic mean and median (Table 3). Wastewater treatment plant in Gródek discharged into the waters of Supraśl mostly $\mathrm{Fe}^{2+/ 3+}$, whose average amount was equal to $76.48 \mathrm{mg} \cdot \mathrm{h}^{-1} \cdot \mathrm{Pb}^{2+}$ and $\mathrm{Cd}^{2+}$ were the least discharged loads and were equal to 1.10 and 0.93 $\mathrm{mg} \cdot \mathrm{h}^{-1}$ respectively. $\mathrm{Cu}^{2+}$ charge was a few $\mathrm{mg} \cdot \mathrm{h}^{-1}$, $\mathrm{Zn}^{2+}$ dozen and $\mathrm{Ni}^{2+}$ about $2 \mathrm{mg} \cdot \mathrm{h}^{-1}$. A number of discharged loads of the elements can be presented as follows: $\mathrm{Fe}^{2+/ 3+}>\mathrm{Zn}^{2+}>\mathrm{Cu}^{2+}>\mathrm{Ni}^{2+}>\mathrm{Pb}^{2+}>$ $\mathrm{Cd}^{2+}$. In the Supraśl behind the discharge of sewage from a sewage treatment plant in Gródek, the average charge of $\mathrm{Fe}^{2+/ 3+}\left(0.178 \mathrm{mg} \cdot \mathrm{h}^{-1}\right)$ was the largest and the lowest of $\mathrm{Cd}^{2+}\left(0.001 \mathrm{mg}^{\cdot} \mathrm{h}^{-1}\right)$ (Table 4). Dispersion of results from the mean values was small as evidenced by the value of standard deviation.

Loads of metals in wastewater from sewage treatment in Sokółka were higher in relation to wastewater from treatment plants in Gródek (Table 5). This is related directly to the size of each plant. Sewage treatment plant in Gródek represents a relatively small group of objects. Similar to wastewater treatment plants in Gródek, Sokółka discharged largest load of $\mathrm{Fe}^{2+/ 3+}$ and $\mathrm{Zn}^{2+}$, and the smallest of $\mathrm{Pb}^{2+}$ and $\mathrm{Cd}^{2+}$ (Tables 3 and 5). In the case of wastewater treatment plant in Sokółka a slightly different number of discharged loads was observed, which was as follows: $\mathrm{Fe}^{2+/ 3+}>\mathrm{Zn}^{2+}>\mathrm{C}$ $\mathrm{u}^{2+}>\mathrm{Ni}^{2}>\mathrm{Cd}^{2+}>\mathrm{Pb}^{2+}$. In Sokołda waters the high-

Table 3. Loads of metals in treated wastewater from sewage treatment plants in Gródek

\begin{tabular}{|c|c|c|c|c|c|c|}
\hline Element & Unit & Arithmetic mean & Median & Minimum & Maximum & Standard deviation \\
\hline $\mathrm{Pb}^{2+}$ & \multirow{6}{*}{$\mathrm{mg} \cdot \mathrm{h}^{-1}$} & 1.10 & 0.90 & 0.23 & 2.37 & 1.05 \\
\hline $\mathrm{Cd}^{2+}$ & & 0.93 & 0.90 & 0.53 & 1.38 & 0.36 \\
\hline $\mathrm{Cu}^{2+}$ & & 6.07 & 7.07 & 2.17 & 7.94 & 2.64 \\
\hline $\mathrm{Fe}^{2+/ 3+}$ & & 76.48 & 63.05 & 42.87 & 136.97 & 41.48 \\
\hline $\mathrm{Ni}^{2+}$ & & 1.90 & 1.80 & 0.76 & 3.27 & 1.11 \\
\hline $\mathrm{Zn}^{2+}$ & & 13.37 & 14.10 & 1.07 & 24.20 & 10.11 \\
\hline
\end{tabular}

Table 4. Loads of metals in water of the Supraśl river behind discharge of sewage from sewage treatment plant in Gródek

\begin{tabular}{|c|c|c|c|c|c|c|}
\hline Element & Unit & Arithmetic mean & Median & Minimum & Maximum & Standard deviation \\
\hline $\mathrm{Pb}^{2+}$ & \multirow{6}{*}{$m g \cdot h^{-1}$} & 0.002 & 0.002 & 0.001 & 0.004 & 0.001 \\
\hline $\mathrm{Cd}^{2+}$ & & 0.001 & 0.001 & 0.000 & 0.002 & 0.001 \\
\hline $\mathrm{Cu}^{2+}$ & & 0.010 & 0.009 & 0.002 & 0.020 & 0.006 \\
\hline $\mathrm{Fe}^{2+/ 3+}$ & & 0.178 & 0.180 & 0.090 & 0.273 & 0.069 \\
\hline $\mathrm{Ni}^{2+}$ & & 0.008 & 0.006 & 0.004 & 0.016 & 0.004 \\
\hline $\mathrm{Zn}^{2+}$ & & 0.006 & 0.004 & 0.002 & 0.012 & 0.004 \\
\hline
\end{tabular}


Table 5. Loads of metals in treated wastewater from sewage treatment plants in Sokółka

\begin{tabular}{|c|c|c|c|c|c|c|}
\hline Element & Unit & Arithmetic mean & Median & Minimum & Maximum & Standard deviation \\
\hline $\mathrm{Pb}^{2+}$ & \multirow{6}{*}{$m g \cdot h^{-1}$} & 8.82 & 9.58 & 0.04 & 16.02 & 7.43 \\
\hline $\mathrm{Cd}^{2+}$ & & 11.45 & 11.63 & 5.29 & 17.21 & 5.30 \\
\hline $\mathrm{Cu}^{2+}$ & & 51.84 & 49.97 & 24.80 & 82.66 & 30.75 \\
\hline $\mathrm{Fe}^{2+/ 3+}$ & & 884.20 & 892.40 & 421.42 & 1330.56 & 403.95 \\
\hline $\mathrm{Ni}^{2+}$ & & 34.09 & 27.76 & 20.99 & 59.87 & 18.21 \\
\hline $\mathrm{Zn}^{2+}$ & & 159.55 & 194.26 & 19.37 & 230.22 & 95.31 \\
\hline
\end{tabular}

Table 6. Loads of metals in Sokołda river behind the discharge of sewage from a sewage treatment plant in Sokółka

\begin{tabular}{|c|c|c|c|c|c|c|}
\hline Element & Unit & Arithmetic mean & Median & Minimum & Maximum & Standard deviation \\
\hline $\mathrm{Pb}^{2+}$ & \multirow{6}{*}{$m g \cdot h^{-1}$} & 0.010 & 0.008 & 0.005 & 0.020 & 0.005 \\
\hline $\mathrm{Cd}^{2+}$ & & 0.003 & 0.002 & 0.001 & 0.005 & 0.002 \\
\hline $\mathrm{Cu}^{2+}$ & & 0.025 & 0.022 & 0.006 & 0.043 & 0.015 \\
\hline $\mathrm{Fe}^{2+/ 3+}$ & & 0.487 & 0.432 & 0.165 & 0.735 & 0.207 \\
\hline $\mathrm{Ni}^{2+}$ & & 0.049 & 0.030 & 0.016 & 0.133 & 0.042 \\
\hline $\mathrm{Zn}^{2+}$ & & 0.019 & 0.024 & 0.002 & 0.032 & 0.013 \\
\hline
\end{tabular}

est average load was from $\mathrm{Fe}^{2+/ 3+}\left(0.487 \mathrm{mg} \cdot \mathrm{h}^{-1}\right)$ and the lowest from $\mathrm{Cd}^{2+}\left(0.003 \mathrm{mg}^{\cdot h^{-1}}\right)$ (Table 6). The standard deviation does not indicate a large deviation from the average.

Similarly, as in the case of the two earlier facilities, the largest discharges load from Bialystok was from $\mathrm{Fe}^{2+/ 3+}$ and $\mathrm{Zn}^{2+}$ (Table 7). The lowest discharge from the wastewater load was $\mathrm{Pb}^{2+}$ and $\mathrm{Cd}^{2+}$. The loads of other elements were more than ten times greater than those discharged from the treatment plant in Sokolka and more than one hundred times greater than those form Gródek. The values of metal loads, as in other objects, were directly related to the volume of wastewater and the average volume of monthly wastewater inflow. The sewage treatment plant in Bialystok showed the same number of discharged loads as wastewater treatment plant in Sokółka $\left(\mathrm{Fe}^{2+/ 3+}>\right.$ $\left.\mathrm{Zn}^{2+}>\mathrm{Cu}^{2+}>\mathrm{Ni}^{2+}>\mathrm{Cd}^{2+}>\mathrm{Pb}^{2+}\right)$. In the Biała waters the greatest load was form $\mathrm{Fe}^{2+/ 3+}\left(1,354 \mathrm{mg} \cdot \mathrm{h}^{-1}\right)$ and the lowest form $\mathrm{Cd}^{2+}\left(0.017 \mathrm{mg} \cdot \mathrm{h}^{-1}\right)$ (Table 8). Loads of metals in waters of the Biała in Dobrzyniewo were greater than those observed in the Supraśl waters (point Gródek) and the Sokołda (point Sokółka). It is related to load values in wastewater discharged by the analyzed facilities.

Comparing to all the studied treatment plants, significantly greater loads of the individual elements were obtained by Deycarda et al. [2014] in a sewage treatment plant in Fargue Louis, France. The studies of wastewater from treatment plant was characterized by the equivalent number of in- habitants at 287,000 and average daily flow in the range of 80,000 to $200,000 \mathrm{~m}^{3} \cdot \mathrm{d}^{-1}$.

Statistical calculations revealed high Pearson correlation coefficients between the charges of most metals in wastewater discharged by the plant in Gródek and their loads in the Supraśl waters. These relationships were as follows: $\mathrm{Pb}^{2+}-\mathrm{r}=0.88 ; \mathrm{Cd}^{2+}-\mathrm{r}=0.98 ; \mathrm{Fe}^{2+/ 3+},-\mathrm{r}=0.45$; $\mathrm{Ni}^{2+}-\mathrm{r}=0.55 ; \mathrm{Zn}^{2+}-\mathrm{r}=0.86$. The calculation results indicate a high metal charges connection in the Supraśl waters from the Gródek area with loads of metals in wastewater discharged from sewage treatment plant in Gródek.

Loads of $\mathrm{Cd}^{2+}$ and $\mathrm{Cu}^{2+}$ in the wastewater discharged from wastewater treatment plant in Sokółka shaped the loads of these metals in Sokołda waters at the point of Sokółka. A strong dependence was achieved at the level for $\mathrm{Cd}^{2+}-$ $\mathrm{r}=0.89$ and $\mathrm{Cu}^{2+}-\mathrm{r}=0.69$. In this case only two strong dependences were obtained in accordance to Gródek.

Loads of $\mathrm{Cd}^{2+}$ and $\mathrm{Zn}^{2+}$ in Biała waters at the point of Dobrzyniewo are strongly dependent to loads of these metals in wastewater discharged from sewage treatment plant in Bialystok. The dependence show Pearson coefficients for: $\mathrm{Cd}^{2+}$ $-\mathrm{r}=0.77 ; \mathrm{Zn}^{2+}-\mathrm{r}=0.81$. For other metals there was no sufficiently strong relations observed.

The values of the studied metals loads were affected by the flow of water and the concentration of the metal. It is worth to note differences in metal concentrations in treated wastewater and in 
Table 7. Loads of metals in treated wastewater from sewage treatment plants in Białystok

\begin{tabular}{|c|c|c|c|c|c|c|}
\hline Element & Unit & Arithmetic mean & Median & Minimum & Maximum & Standard deviation \\
\hline $\mathrm{Pb}^{2+}$ & \multirow{6}{*}{$\mathrm{mg} \cdot \mathrm{h}^{-1}$} & 151.20 & 172.08 & 31.14 & 228.96 & 88.92 \\
\hline $\mathrm{Cd}^{2+}$ & & 160.56 & 159.12 & 95.47 & 227.88 & 57.24 \\
\hline $\mathrm{Cu}^{2+}$ & & 808.92 & 889.56 & 368.03 & 1088.64 & 328.68 \\
\hline $\mathrm{Fe}^{2+/ 3+}$ & & 4995.36 & 4700.16 & 4247.64 & 6333.12 & 984.24 \\
\hline $\mathrm{Ni}^{2+}$ & & 222.48 & 207.00 & 122.69 & 352.80 & 105.12 \\
\hline $\mathrm{Zn}^{2+}$ & & 828.00 & 967.68 & 144.14 & 1233.00 & 511.20 \\
\hline
\end{tabular}

Table 8. Loads of metals in the Biała river behind discharge of sewage from a sewage treatment plant in Białystok

\begin{tabular}{|c|c|c|c|c|c|c|}
\hline Element & Unit & Arithmetic mean & Median & Minimum & Maximum & Standard deviation \\
\hline $\mathrm{Pb}^{2+}$ & \multirow{6}{*}{$\mathrm{mg} \cdot \mathrm{h}^{-1}$} & 0.027 & 0.025 & 0.011 & 0.052 & 0.015 \\
\hline $\mathrm{Cd}^{2+}$ & & 0.017 & 0.016 & 0.007 & 0.032 & 0.009 \\
\hline $\mathrm{Cu}^{2+}$ & & 0.139 & 0.102 & 0.007 & 0.388 & 0.120 \\
\hline $\mathrm{Fe}^{2+/ 3+}$ & & 1.354 & 1.312 & 0.044 & 2.361 & 0.747 \\
\hline $\mathrm{Ni}^{2+}$ & & 0.099 & 0.060 & 0.041 & 0.252 & 0.080 \\
\hline $\mathrm{Zn}^{2+}$ & & 0.156 & 0.123 & 0.043 & 0.311 & 0.095 \\
\hline
\end{tabular}

the waters of the receiver, such asin Gródek vicinity. In the case of $\mathrm{Fe}^{2+/ 3+}$ the observed differences were quite large, in the case of $\mathrm{Cd}^{2+}$ and $\mathrm{Ni}^{2+}$ the differences were almost twice as large, and in the case of $\mathrm{Zn}^{2+}$ (up to four times). The Suprasl river flow is comparable in points Gródek and Sokołda (Sokółka) and Biała (Dobrzyniewo) and Gródek wastewater treatment plant by the smallest throughput. The smallest loads of metals in the treated wastewater from sewage treatment plant in Gródek of all studied also considering the issue of the achieved correlation. Probably, improper work of sewage treatment plants in Gródek is the cause of correlations between the studied charges which have also been confirmed in other studies conducted by the authors of the study. Correlated loads of $\mathrm{Cd}^{2+}$ in all three cases are confirmed in large differences in the concentration of the metal in the treated wastewater and water loads. A similar situation also occurs partly in the case of $\mathrm{Zn}^{2+}$.

\section{CONCLUSIONS}

1. During the studies the concentration difference detected for $\mathrm{Cd}^{2+}, \mathrm{Fe}^{2+/ 3+}, \mathrm{Ni}^{2+}$ and $\mathrm{Zn}^{2+}$ in the treated wastewater and the water receivers affect the formation of the loads of these metals.

2. Studies have shown the impact of metals loads in treated wastewater on loads of metals in the receivers waters based on the calculated correlation. The highest correlation was found between charges of $\mathrm{Pb}^{2+}-\mathrm{r}=0.88 ; \mathrm{Cd}^{2+}-\mathrm{r}=$ $0.98 ; \mathrm{Fe}^{2+/ 3+},-\mathrm{r}=0.45 ; \mathrm{Ni}^{2+}-\mathrm{r}=0.55 ; \mathrm{Zn}^{2+}-$ $\mathrm{r}=0.86$ in the case of wastewater treatment in Gródek and Supraśl water.

3. Loads of certain metals in the wastewater from sewage treatment plant in Bialystok were more than ten times larger than the loads discharged by the plant in Sokółka, and more than one hundred times larger than the loads from Gródek. The loads depended on the size of sewage treatment technologies.

4. For all the studied facilities, there were no facility that exceeded the limits set in the Decree of the Minister of the Environment of 18 November 2014 on the conditions to be met when introducing sewage into water or soil.

\section{REFERENCES}

1. Brykała D. 2009. Przestrzenne i czasowe zróżnicowanie odpływu rzecznego w dorzeczu Skrwy Lewej, PAN IGiPZ, Warszawa.

2. Brzóska M., Gałażyn-Sidorczuk M., Lewandowska I. 2007. Ocena zanieczyszczenia metalami ciężkimi wód zalewu Dojlidy położonego na terenie Białegostoku - badania w latach 2006-2007. Ochrona środowiska i zasobów naturalnych $\mathrm{Nr} 31$, Instytut Ochrony Środowiska, Warszawa.

3. Deycard V.N., Schafer J., Blanc G., Coynel A., Petit J., Lancelucar L., Dutruch L., Bossy C., Ventura A. 2014. Contribution and potential impacts 
of seven priority substances (As, $\mathrm{Cd}, \mathrm{Cu}, \mathrm{Cr}, \mathrm{Ni}$, $\mathrm{Pb}$ and $\mathrm{Zn}$ ) to a major European Estuary (Gironde Estuary, France) from urban wastewater, Marine Chemistry, no. 167, 123-134.

4. Duffy S.J., van Loon G.W. 2008. Chemia środowiska. Wydawnictwo Naukowe PWN, Warszawa.

5. Florczyk H., Gołowin S. 1980. Metale ciężkie w wodach powierzchniowych, płynących Polski. Ochrona Środowiska nr 1.

6. Hermanowicz W., Dojlido J., Dożańska W. i in. 1999. Fizyko-chemiczne badania wody i ścieków. Arkady, Warszawa.

7. Kaniuczak J., Augustyn Ł., 2011. Zawartość jonów metali w wodach powierzchniowych przeznaczonych do zaopatrzenia ludności w wodę do spożycia, Inżynieria Ekologiczna, nr 27, 33-45.

8. Kociołek-Balawejder E., Stanisławska E. 2012. Chemia środowiska. Wydawnictwo Uniwersytetu Ekonomicznego we Wrocławiu, Wrocław.

9. Palapa T.M., Maramis A.A., 2015. Heavy metlas in water of stream near an amalgamation tailing ponds in Talawaan-Tatelu Gold Mining, North Sulawesi, Indonesia. Procedia Chemistry, no. 14, 428-436.

10. Piekutin J. 2008. Ocena zanieczyszczenia płynących wód powierzchniowych na terenie powiatu białostockiego. Ochrona Środowiska i Zasobów Naturalnych nr 35/35.

11. Rozporządzenie Ministra Środowiska z dnia 18 listopada 2014, w sprawie warunków, jakie należy spełniać przy wprowadzaniu ścieków do wód lub do ziemi oraz w sprawie substancji szczególnie szkodliwych dla środowiska wodnego.

12. Skorbiłowicz M. 2010. Czynniki i procesy kształtujące obieg składników mineralnych w wodach rzecznych zlewni górnej Narwi. Oficyna Wydawcza Politechniki Białostockiej, Białystok.

13. Trawczyńska A., Tołoczko W., Niewiadomski A., 2009. Zawartość pierwiastków śladowych w wodach Górnej Bzury, Ochrona Środowiska i zasobów Naturalnych, nr 40, 491-496. 